\title{
Institutional frameworks and radical innovation: an analysis of high- and medium-high-technology industries in Germany
}

\author{
Matthew M.C. Allen* \\ Manchester Business School, \\ The University of Manchester, \\ Booth Street West, M15 6PB, UK \\ E-mail: Matthew.allen@mbs.ac.uk \\ *Corresponding author
}

\section{Heinz-Josef Tüselmann}

Centre for International Business and Innovation, Manchester Metropolitan University Business School, Aytoun Street, M1 3GH, Manchester, UK E-mail: h.tuselman@mmu.ac.uk

\section{Maria L. Aldred \\ Manchester Metropolitan University Business School, Aytoun Street, M1 3GH, Manchester \\ E-mail: m.benson@mmu.ac.uk}

\begin{abstract}
Radical innovation is increasingly becoming the focus of attention of both policy makers and senior corporate managers. However, debates within the varieties of capitalism literature on the ease with which radical innovation can be achieved within less de-regulated economies, such as Germany, have tended to focus on the pharmaceutical industry. This article demonstrates that attempts to assess the extent to which the socio-economic institutions typically associated with Germany support radical innovation should be broadened to cover other sectors besides the pharmaceutical industry, as the distinctiveness of that sector has yet to be firmly established. This article proposes theoretical reasons to suggest that the pharmaceutical industry may not be as distinct, in terms of radical innovation, from other sectors as it is often implicitly assumed to be. These arguments are assessed using the large-scale, representative survey data. This paper opens up new areas that can be explored in future research. The core finding is that pharmaceutical firms are not statistically more likely to introduce radical innovations compared to those in many other high-technology and medium-high-technology industries. In addition, works councils and sectoral collective agreements do not hinder the development of new technologies. Both of these findings have important public-policy implications.
\end{abstract}

Keywords: varieties of capitalism; VoC; institutional frameworks; innovation; institutional change; Germany; works councils; sectoral collective agreements. 
Reference to this paper should be made as follows: Allen, M.M.C., Tüselmann, H-J. and Aldred, M.L. (2011) 'Institutional frameworks and radical innovation: an analysis of high- and medium-high-technology industries in Germany', Int. J. Public Policy, Vol. 7, Nos. 4/5/6, pp.265-281.

Biographical notes: Matthew M.C. Allen is a Senior Lecturer in Organisation Studies at Manchester Business School.

Heinz-Josef Tüselmann is a Professor of International Business and he is the Director of the Centre for International Business and Innovation at Manchester Metropolitan University Business School.

Maria L. Aldred is a Senior Lecturer in International Business at Manchester Metropolitan University Business School.

\section{Introduction}

In recent years, there has been a growing interest in radical innovation (see, for example, Audretsch and Aldridge, 2008; Slocum and Rubin, 2008). Such a focus on radical innovation reflects heightened concerns about national competitiveness, the desire to establish strong positions in emerging technologies, and the ambition of ensuring more sustainable energy supplies. However, any public-policy initiatives in this area are likely to have to take into consideration the degree to which radical innovation is possible within different sectors of the economy. In addition, the efficacy of any such policies is likely to be shaped by existing national institutional frameworks (Hall and Soskice, 2001a; Whitley, 2007). However, within a strand of the literature that builds on the varieties of capitalism (VoC) analytical framework (Hall and Soskice, 2001a), several recent studies (Casper, 2009; Casper and Matraves, 2003; Casper and Whitley, 2004; Herrmann, 2008; Lange, 2009) have been restricted to examining the ways in which national institutional frameworks, such as labour market systems, shape radical innovation in the pharmaceutical industry, in general, and in the biotechnology sector, in particular, in Germany. Whilst this emphasis is both highly important and justifiable, it, potentially, runs the risk of downplaying the development of new technologies in other sectors. Indeed, comparisons of the prevalence of radical innovation in workplaces in different sectors have yet to be undertaken. Hence, the distinctiveness of the pharmaceutical industry still needs to be firmly established. This article examines the degree to which radical innovations, based on establishment data, are more likely in the pharmaceutical industry compared to various other manufacturing sectors in Germany.

The study is based on an assessment, using multivariate statistical analysis of a recent large-scale data-set at the workplace level, of the distinctiveness of the pharmaceutical industry in terms of radical innovation compared to other 'high-technology' and 'medium-high-technology' sectors. The survey, commissioned by the Institute for Employment Research (IAB), or Institut für Arbeitsmarkt- und Berufsforschung, in Germany, is the largest of its kind and is carried out at the establishment rather than the firm level. A related survey, the Mannheim Innovation Panel (MIP), which is carried out under the auspices of the Centre for Economic Research (ZEW), is conducted at the firm rather than the workplace level. The IAB's data has four main advantages. Firstly, 
the presence of institutions, such as works councils can vary between different establishments within the same firm. Secondly, and given this variation, the links, if any, between those institutions and innovation outcomes may lead to indeterminacy in the results. Thirdly, establishments within the same firm, especially large diversified ones, may belong to different sectors. Thus, aggregating data at the firm level may lead to a loss of highly pertinent details. Finally, the IAB's sectoral classifications are more nuanced that those in the MIP survey.

The study finds that firms in the pharmaceutical sector are not statistically more likely to introduce radical innovations compared to those in many other high-technology and medium-high-technology industries. Whilst this does not fundamentally impugn the emphasis in the literature to date, it does indicate that the pharmaceutical industry is not as distinctive as it is sometimes implicitly assumed to be. This suggests that other industries should be included in assessments of some of the key, innovation-related arguments of the $\mathrm{VoC}$ framework. The findings have a number of wider public-policy implications, too. For instance, the study demonstrates, importantly, that works councils and sectoral collective agreements, which have been criticised as impediments to the development of new technologies (Phelps, 2007), are not associated, in a statistically significant way, with lower levels of radical innovation (see also Kraft et al., 2011). Therefore, the promotion of more radically innovative technologies in Germany does not hinge upon the deregulation of key labour-market policies.

This paper is structured as follows. The next section sets out the view of the innovation process in the $\mathrm{VoC}$ paradigm and in a related typology proposed by Marsili and Verspagen (2002). It also provides information on the research expectations. By doing so, it puts forward arguments to suggest, firstly, that there are similarities between the innovation process on the pharmaceutical industry and other sectors, and, secondly, that the process of radical innovation in certain other sectors may be aided by Germany's institutional framework. The subsequent section describes the data and methods used to assess the extent to which the pharmaceutical industry is distinct in its ability to innovate in a radical way. The findings and their implications are then discussed. Finally, conclusions are drawn.

\section{Different perspectives on the sectoral innovation process, and research expectations}

This section set outs two complementary perspectives on the innovation process in varying sectors. The first, the $\mathrm{VoC}$ approach, draws a distinction between radical and incremental innovation, whereas the second, a framework developed by Marsili and Verspagen (2002), distinguishes between five broad classifications of the innovation process (see also work by Walz, 2007, that highlights the need for innovation studies to adopt nuanced approaches that take into consideration the specificities of the technology under development).

The VoC paradigm, in short, argues that different socio-economic institutions lay the foundations of firms' competitive - and, hence, countries' comparative - advantages. The main institutions that are of importance include the labour-market system, vocational training, corporate financing and governance, and inter-firm networks. In the first stage of the argument, the ways in which these institutions are configured within a 
country - or, more precisely, within groups of countries that are termed either 'coordinated market economies' (CMEs), such as Germany and Sweden, or 'liberal market economies' (LMEs), such as the UK and the US - offer distinct advantages to firms operating there. For instance, in a CME such as Germany, the presence of strong workplace employee representatives, industry-wide collective wage bargaining, co-determination at the supervisory board level, and business associations that monitor various activities by their members encourage firms to see employees as a fixed rather than a variable cost (Streeck, 1992, 1997). This, in turn, facilitates production strategies that are based on delegating a relatively large degree of autonomy to workers who have firm-specific skills (Hall and Soskice, 2001b; Whitley, 2007).

However, such a strategy - as it is based on long-term commitments between employees and employers as well as between firms and their suppliers - hinders the firm's ability to change the types of products and services that it offers as well as the organisational capabilities upon which they depend quickly. Therefore, incremental innovation or the up-grading of existing products is favoured. By contrast, companies in LMEs will be encouraged to pursue strategies based on radical innovation, as the absence, inter alia, of strong workplace employee representation, powerful business associations and co-determination at the board level will mean that long-term commitments between not only employers and employees, but also firms and their suppliers will be difficult to foster (Allen, 2004; Hall and Soskice, 2001b; Börsch, 2008). They will, however, be more able to reconfigure their capabilities to undertake radical innovations.

In the second key stage in the $\mathrm{VoC}$ framework, this reliance on, for example, different forms of human capital can help to facilitate success in certain product markets. Workers with firm-specific skills will be a prerequisite for, though not a guarantee of (Streeck 1992), success in product markets characterised by incremental innovation, which are said to be 'marked by continuous small-scale improvements to existing product lines and production processes' [Hall and Soskice, (2001b), p.39]. Such markets include machine tools, factory equipment, engines, and transport goods. Workers with general skills, on the other hand, will be a sine qua non in markets in which radical innovation - 'innovative design and rapid product development based on research' [Hall and Soskice, (2001b), p.39] - is the key to success. Products markets that are characterised by radical innovation include biotechnology, semiconductors, and telecommunications equipment (Tylecote and Ramirez, 2006).

It is against this backdrop that assessments of the extent to which firms in the pharmaceutical and bio-tech industry in Germany gain their importance. The pharmaceutical industry, which encompasses biotechnology, has been chosen as the basis for assessments of the extent to which German firms are able to compete in radically innovative industries in a number of recent studies. As this industry is strongly marked by radical innovation, any evidence that indicates that German firms can be as competitive as ones based in 'LMEs' has profound implications for the VoC approach. For instance, Herrmann (2008, p.638) has noted that the VoC 'literature has difficulties in explaining how an innovative biotech industry could develop in rigid economies like Germany ... How can firms compete despite comparative institutional disadvantages?' Similarly, Lange (2009, pp.182-183) justified the selection of the 'pharmaceutical biotechnology industry' in Germany as the basis for evaluating the $\mathrm{VoC}$ approach and its claims on innovation on the grounds that, according to that literature, 


\begin{abstract}
"the characteristics of this industry and the institutional framework of Germany do not fit together. Whereas the dominant institutions of the German economy are seen to be conducive to incremental innovations and detrimental to radical ones, this segment of the biotech industry is characterized by radical innovations."
\end{abstract}

Casper (2009, p.209) has noted that the choice of this industry in such studies has been made in order 'to contest the saliency of one of the VoC approach's core claims: that patterns of comparative institutional advantage structure patterns of national specialisation across different types of innovation focused industries.' As Casper also highlights, the findings for the pharmaceutical sector have wider implications for any attempts by firms to pursue - or by policy makers to facilitate firms' - competitive strategies based on radical innovation. Therefore, assessments of the extent to which pharmaceutical and bio-tech firms in Germany are able to pursue strategies based on radical innovation has profound implications for the VoC paradigm: if companies can succeed in this sector in Germany, then they are likely to be able to succeed using the same strategy in other sectors, too (see also, Casper et al., 1999). However, the extent to which the pharmaceutical industry is distinct from other manufacturing sectors has yet to be firmly established.

Refining Pavitt's (1984) well-known taxonomy, Marsili and Verspagen (2002) provide an alternative and relatively nuanced way to classify the innovation process in different industrial sectors. Their categorisation of various manufacturing sectors provides a useful starting point for an assessment of the extent to which innovation in the pharmaceutical industry is distinct from that in other sectors. For instance, rather than seeing the innovative activities of the pharmaceutical industry as having qualities that are more pronounced than - or, in some way, different to - those of other sectors, Marsili and Verspagen (2002) see such endeavours as sharing characteristics with the electrical/electronic industries, which cover, inter alia, computers, electric motors, electrical equipment, electronic components and telecommunications equipment.

These industries are grouped together within a 'science-based category' that has a knowledge base in the life sciences and physics. One of the characteristics of this category is the "high specificity of knowledge applications ... and high cumulativeness of innovation' [Marsili and Verspagen, (2002), p.797]. This implies not only that, in part, innovations build on previous knowledge and, significantly, innovations, but also that innovators require a detailed understanding of the use of those previous innovations. More importantly, for radical innovation, this category is also marked by product innovation that benefits directly from absorbing scientific advances in academic research. These shared characteristics provide the basis for expecting the radical innovation patterns in the pharmaceutical and computers, communications equipment, and electrical machinery to be similar. Therefore, the propensity of firms in the pharmaceutical industry to develop new technologies may be no greater than it is in other industries within the 'science-based' sector. This is in contrast to the VoC paradigm in which the pharmaceutical and computer industries are seen as being distinct from the communications-equipment and electrical-machinery sectors, as the latter two are, it is contended, characterised by incremental rather than radical innovation.

The second broad category in Marsili and Verspagen (2002) typology is the 'fundamental processes regime'. This is associated with the chemical industry. One of the features of such industries is that innovation 'is mainly process innovation' (p.798). As radical innovation is measured in this article (see below) as the introduction of products 
or services for which a new market had to be created, this suggests that radical innovation is likely to be less pronounced in the chemical industry than it is in science-based sectors, such as the pharmaceutical industry. This is not to deny the possibility that new processes could lead to the commercialisation of new products; process innovation is, however, likely to concentrate on supplying existing products or services more efficiently [Block and Keller, (2009), p.465]. Interestingly, the VoC literature does not directly address the type of innovation that is likely to characterise the chemical industry.

The third sector within Marsili and Verspagen's (2002) taxonomy covers industries that are based upon 'complex (knowledge)' systems that combine mechanical, electrical/electronic and transportation technologies. As Marsili and Verspagen (2002, p.798) note, the 'distinctive characteristic of this regime is the high degree of differentiation of technological competencies developed by firms, especially in upstream production technologies, and of external sources of knowledge, including an important, though indirect, contribution by academic research.' In general, a corollary of these characteristics is that innovations will not tend to be radical, as they, firstly, must fit into an existing and highly complex system and, secondly, are likely to require adjustments by collaborating firms that may be costly for them to undertake. Therefore, within the motor vehicles industry, which is covered by this sector, incremental innovation would tend to be favoured over radical innovation. The VoC literature would expect innovation in this sector to be based on incremental rather than radical innovation. This is not, however, to say that radically new products are not possible in these sectors. The Toyota Prius may represent one such example (for more on this, see Nonaka and Peltokorpi, 2006).

Relying on mechanical engineering technologies, innovation in Marsili and Verspagen's (2002) fourth sector, the product-engineering regime, which encompasses special purpose machinery, electrical and mechanical instruments and non-electrical machinery, is said to benefit, amongst other things, from external contributions of knowledge mainly from users. However, gaining this knowledge may not be as straightforward as it may first appear. For instance, acquiring a solid understanding of users' requirements may be problematic if the knowledge base is complex and distributed across both a range of individuals within the firm and technical areas. Moreover, the establishment of a high level of commitment between a manufacturer and a customer, which is likely to be necessary before any customer-specific knowledge and skills are developed (Whitley, 2007), may take a relatively long period of time. In addition, disputes over the ways in which the financial benefits that may result from any collaboration are to be distributed as well as concerns over ex post facto opportunism may preclude the sharing of information between the two organisations.

Such concerns are likely to be heightened or ameliorated by the socio-economic framework within which strategic actors operate. As Whitley (2007, p.180) has noted the extent to which firms share knowledge with business partners can be influenced by, for example, membership of industry associations. In countries, such as Germany, where business associations are comparatively strong, these groups can engage in joint standard setting and encourage knowledge to be diffused amongst their members. These associations can also monitor behaviour to ensure norms of appropriate firm behaviour are met (Culpepper, 2001). Within such a setting, gaining knowledge about users' requirement may be less problematic than it is in other countries.

It can, however, be argued, as it is within the $\mathrm{VoC}$ literature, that mutual commitments between firms in an industry network are likely to constrain the degree of radical technological innovations, as these will tend to undermine existing organisational 
competencies [Hall and Soskice, 2001b; Whitley, (2007), p.180]. On the other hand, it can be argued that those close ties between firms may also facilitate the generation of relatively new ways of solving existing or emerging problems. This may, for instance, be particularly true in the scientific instruments sector, broadly defined, in which new medical techniques create the possibility for firms to introduce radical innovations in the form of equipment that can perform certain highly novel tasks.

An example from the medical equipment sector illustrates this argument. New techniques that enable the modification or derivation of various stem cells create the possibility of determining the strength of a substance by means of a test on an organism. Such tests of organisms rely on having sufficiently high numbers of cells that are capable of differentiation into more than one type of mature cell or tissue. Whilst detecting and harvesting these cells can be done manually, automated systems can perform this function. However, devising such equipment requires an understanding of users' requirements, biological material, mechanical engineering, imaging and computer software. As such competencies are unlikely to be present in a single organisation, cooperation will be necessary. Collaboration between Life \& Brain GmbH and Aviso $\mathrm{GmbH}$, two German companies, resulted in an automated scientific instrument that is capable of performing the tasks outlined above (Aviso, 2008).

This example shows that there are other sectors of the German economy that, whilst having innovation characteristics that are dissimilar to those of in the pharmaceutical industry, may, to a certain extent, be marked by radical innovation. In short, radically innovative activities in the 'product-engineering' sector may, in some areas, be supported by Germany's socio-economic institutional framework. Further evidence to support the argument that German companies may be capable of performing well in the scientific instruments industry, which forms part of the 'product-engineering' sector and which has been characterised as being marked by radical innovation, can be found in Allen et al. (2006).

The final category in Marsili and Verspagen's (2002) typology relates to industries involved in continuous processes, such as metals and building materials, textiles, paper, food and tobacco. This sector is characterised by low levels of innovation (Marsili and Verspagen, 2002). Therefore, it is unlikely that the industries in this sector will have a higher likelihood of engaging in radical innovation than the pharmaceutical industry.

\section{Methodology}

\subsection{Data}

The data are drawn from a representative annual survey of employers commissioned by the Institute for Employment Research (IAB). It is the largest survey of its kind. The IAB is the research arm of the Bundesagentur für Arbeit, or Federal Labour Office. It is the only comprehensive nation-wide survey based on workplaces in Germany. The survey is completed in face-to-face interviews between an employee of TNS Infratest Sozialforschung, Munich, and a senior manager at the establishment (for more information on this dataset, see Kölling, 2000). The recurring annual information on employment issues are complemented by topics of current interest. The 2007 survey included a number of questions related to innovation (IAB, 2007). 
From the 2007 survey, all private-sector manufacturing workplaces with more than 50 employees that fall into the high-technology and medium-high-technology industries of the OECD classification system of sectors according to technology intensity were selected. This yielded a sample of 443 workplaces. Workplaces with at least 50 employees were included in order to ensure that the results are not biased by the large number of small enterprises that do not have works councils (Addison et al., 2004). The rationale for focusing on the high- and medium-high-tech industries is twofold. Firstly, and in line with the Marsili and Verspagen (2002) typology outlined above, medium-low and low-tech industries are 'continuous process' sectors, characterised by low levels of innovation (Marsili and Verspagen, 2002). Thus, it is, prima facie, unlikely that industries in this sector will exhibit a higher propensity in radical innovation than the pharmaceutical industry. Secondly, as radical innovation is more likely in the high- and medium-high-tech industries, the exclusion of the medium-low and low-tech industries provides for a more precise examination of the degree of distinctiveness of the pharmaceutical industry. Following the OECD technology classification system, the high-tech industries in our sample included 'pharmaceuticals' 'radio, television and communications equipment', and 'scientific instruments'. The medium-high-tech industries included 'motor vehicles', 'electrical machinery' and 'chemicals (excluding pharmaceuticals)'. Unfortunately, the IAB did not release data on the high-tech industries 'aircraft and spacecraft' and 'computers and office machinery', because of insufficient number of cases in these industries.

\subsection{IAB 2007 survey: forms of innovation and operationalisation of radical innovation}

As noted above, the 2007 IAB Survey (IAB, 2007) contained a number of questions on innovation. Three questions, in particular, relate to different types of innovation. Whilst it is only the question that covers radical innovation that will be used in this study, the other two questions have been provided here in order to illustrate the differences between the questions, and, hence, the rationale for basing an establishment's ability to undertake 'radical innovation' on the response to one of those three questions. The relevant questions, which have been translated by the authors and which have the same emphasis as in the original, are:

1 In the last two years, has your establishment improved or developed further a product or service that you already offered?

2 In the last two years, have you introduced into your product range a product or service that was already available on the market?

3 In the last two years, have you introduced into your product range a completely new product or service for which a new market had to be created?

The first question can be interpreted as relating to incremental innovation; the second, to mimetic innovation; and the third, to radical innovation. Although it can be argued that the operationalisation of the concept of 'radical innovation' is based on the responses of senior managers, there are a number of reasons why this is a valid measure of the concept. Firstly, the wording of the question captures two of the three quintessential aspects of radical innovation, as defined in an important paper by Dahlin and Behrens (2005). They contend that a radical innovation must be novel, unique, and have an impact 
on future technology. The part of the question that refers to 'a completely new product or service' captures the novel aspect of Dahlin and Behrens' (2005) definition, and the emphasis on 'a new market [that] had to be created' encompasses the unique facet of that definition. It is only the third aspect that is not captured, and that, arguably, would require a longitudinal study. Secondly, the European Community's innovation surveys use similarly worded questions. Thirdly, Lorenz and Lundvall (2006) have noted that the 'new to market'/'new to firm' distinction captures important aspects of the differences between radical and incremental innovation, as innovations that are new to the market require firms to utilise new knowledge. Fourthly, the proxy for radical innovation used in this study has overlaps with those in other studies, such as Lettl et al. (2006), Lilien et al. (2002), and Von Hippel et al. (2000). Table 1 presents the proportion of the respondents answered 'yes' to the three questions above. As anticipated by the VoC framework, radical innovation is, across the sample, less common than mimic innovation and, $a$ fortiori, incremental innovation.

Table 1 Different forms of innovation within workplaces

\begin{tabular}{lc}
\hline Type of innovation & Percentage \\
\hline Incremental & 86.7 \\
Mimetic & 47.9 \\
Radical & 39.1 \\
$\mathrm{~N}$ & 443 \\
\hline
\end{tabular}

Source: IAB Establishment Panel (2007); own calculations

\subsection{Variables, measurement and estimation}

The dependent variable is the incidence of radical innovation, operationalised as discussed in the preceding section by the question of whether, in the last two years, the establishment has introduced into their product range a completely new product or service for which a new market had to be created. This variable is measured by binary variable $(1=$ yes, $0=$ no). The independent variables of interest are the three high-tech industries, 'pharmaceuticals' 'radio, television and communications equipment', and 'scientific instruments', as well as the three medium-high-tech industries included, 'motor vehicles', 'electrical machinery' and 'chemicals (excluding pharmaceuticals)' (see preceding section). These were measured as dummy variables.

In order to account for factors other than industry that might influence the ability of firms to undertake radical innovation and to avoid spurious results, we included, based on previous related studies (Addison et al., 2004; Kraft et al., 2011), establishment size, the presence of a works council and whether the establishment is subject to a sectoral collective agreement, as control variables in the statistical analysis. Establishment size was measured by number of employees. However, as this variable is skewed, its log was taken. This is in line with previous studies (Addison et al., 2004; Tether, 2002). The two industrial relations institutions were measured as binary variables $(1=$ yes, $0=$ no). Whilst it is expected that firm size will have a positive effect on the propensity to undertake radical innovation, the impact of works council and sectoral collective agreements is less clear cut. On the one hand, the corollaries of the VoC arguments are that these institutions will not promote radical innovation; on the other, where inter-firm 
authority sharing is, as noted above, a sine qua non for radical innovation, these institutions may promote such outcomes.

The statistical analysis is conducted using multivariate analysis. We estimated a regression model that includes all variables to ascertain whether there are any differences between sectors that hold after allowing for the influence of the control variables. Since the dependent variable is dichotomous $(1-0)$, we estimate a logistic regression model (Menard, 1995; Myers, 1990). With regard to the industry dummies, the pharmaceutical industry acts as reference category. Checks for collinearity between the independent variables indicated no multicollinearity problems. We examined the robustness of the regression results by moderately altering the set of control variables as well as by running a binary probit instead of a binary logistic regression model. These showed that the regression results concerning the independent variables of interest remained robust to these alterations.

\section{Results and discussion}

Table 2 present the regression results. The diagnostics show that the empirical model performs well. The Hosmer and Lemeshow goodness-of-fit test shows that the model provides a good fit for the data, and that the null hypothesis that there is no difference between the observed and the predicted values of the outcome variable should not be rejected. The model chi-square is highly significant, demonstrating the meaningfulness of the regression. The Nagelkerke $\mathrm{R}^{2}$, though not high, is acceptable for logistic regressions and the nature of our data, and is in line with related studies based on binary regression models (Herrmann, 2008; Bluhm and Martens, 2009).

Table 2 Logistic regression results

\begin{tabular}{lcc}
\hline & Odds ratio, exp $(B)$ & Standard error \\
\hline Constant & 0.162 & $0.736^{*}$ \\
Log of the number of employees & 1.388 & $0.097^{* *}$ \\
Works council dummy & 0.904 & 0.292 \\
Sectoral collective agreement dummy & 1.266 & 0.238 \\
Radio, television and communications equipment & 0.900 & 0.619 \\
Scientific instruments & 0.974 & 0.587 \\
Motor vehicles & 0.256 & $0.582^{*}$ \\
Electrical machinery & 0.885 & 0.579 \\
Chemicals excl. pharmaceuticals & 0.611 & 0.582 \\
& & \\
Model $\chi^{2}(8)$ & $37.915 * *$ & .11 \\
Nagelkerke R ${ }^{2}$ & 443 & \\
Number of cases & & \\
\hline
\end{tabular}

Notes: '**' statistically significant at the $1 \%$ level, and ' $*$ ' at the $5 \%$ level.

Reference category for industry dummies: 'Pharmaceutical industry'.

Source: IAB 2007 Establishment Panel; own calculations 
With regard to the control variables, establishment size is, as expected, positively and significantly associated with the likelihood to undertake radical innovations. However, neither the existence of a works council nor the subscription to a sectoral collective agreement seems to have a significant effect on the propensity to undertake radical innovations. In other words, they seem to neither help nor hinder the development of new technologies in a statistically significant way. This is, in itself, an important finding, as these institutions are often criticised as impediments to the development of new technologies (see the debates in Höpner, 2004; Tüselmann et al., 2007). The results do not support these criticisms. Indeed, the findings suggest that the presence of a works council and adherence to a sectoral collective agreement do not hinder organisational changes, including, potentially, job cuts, that are likely to foreshadow or accompany the development of new technologies as critics contend (see, for example, Phelps, 2007).

With the exception of establishments in the motor vehicle industry, workplaces in all other high- and medium-high-tech industries are not significantly more likely to undertake radical innovations compared to those in the pharmaceutical industry. In the motor vehicle industry, radical innovations are significantly less likely than they are in the pharmaceutical industry. This difference is significant at the $5 \%$ level. This result is as anticipated, given the complex interdependencies associated with the product architectures of goods in this sector. This complexity is likely to mean that any changes to components have to be integrated with several other parts of the vehicle. This, in turn, is likely to limit the extent to which radically new components can be incorporated into products. Hence, incremental innovation will tend to be favoured.

The other results are somewhat surprising given the focus of much of the literature to date. Indeed, the implicit assumption of studies that have been designed to assess the extent to which radical innovation is possible in Germany is that the pharmaceutical industry is the most appropriate choice of sector. However, as the results show, that sector is not more likely, in a statistically significant way, to introduce radical innovations. These results can be explained in terms of the framework proposed here. For instance, as discussed above, Marsili and Verspagen (2002) have argued that a group of industries share the same innovation characteristics. Their 'science-based' sector covers the pharmaceutical industry, communications equipment and the electrical machinery industry. The results support this grouping. For both the 'radio, television and communications equipment' and 'electrical machinery' sectors, radical innovation is not statistically less likely than it is in the pharmaceutical industry. This would suggest that the innovation characteristics of the pharmaceutical industry are not as distinct as they are often assumed to be within assessments of the $\mathrm{VoC}$ analytical framework. These results also suggest that the classification of communications-equipment and electricalmachinery sectors as incremental innovators within the $\mathrm{VoC}$ paradigm may have overlooked important activities-based around the development of new technologies in them.

Another sector also conforms to the expectations provided above. The results reveal that radical innovation in the 'scientific instruments' sector is no less likely, in a statistically significant way, than it is in the pharmaceutical industry. As noted above, however, the innovation characteristics of this industry are different to those in the pharmaceutical industry. This does not preclude the possibility that radical innovations may be commercialised in the sector. This finding may indicate that the ways in which institutions shape radical innovation patterns vary between sectors. At a theoretical level, the institutions that are typically associated with the German economy may, contrary to 
the expectations in the VoC literature, actually help firms that wish to commercialise radical innovations overcome some of the coordination and collaboration problems that they are likely to encounter during the development of radically new technologies in this sector. This research certainly cannot make any definitive statements about whether or not institutions are shaping outcomes in this way. There is, however, prima facie evidence to suggest that this might be happening.

The other sector that is no less likely to develop radically new technologies than the pharmaceutical industry is the 'chemicals excluding pharmaceuticals' sector. This does not conform to the expectations outlined above. This is certainly a surprising result given the distinction that is commonly made between the technologies and innovation characteristics that underpin these two sectors (see, for instance, Allen et al., 2006; Dosi et al., 2006; Fioretos, 2001; Marsili and Verspagen, 2002; OECD, 2008). However, the sectoral category may conceal a great deal of variation in the activities of establishments within it. For instance, W.L. Gore and Associates is a highly innovative multinational company, and many of its new-to-market innovations can be subsumed within the activities of the 'chemical industry'. Other variations may result from the characteristics of the establishments: larger and older establishments may, on the whole, seek to improve existing products and processes that lead to incremental innovation, whereas smaller, more recently established ones may focus on the development of radically new products and services. Although the data here do not allow for an examination of such potential reasons to be undertaken, the results do highlight areas of potentially fruitful future research.

\section{Conclusions}

This research has a number of important implications; it also, however, suffers from some limitations. Firstly, in contrast to many recent studies that have used qualitative and/or case study research methods, this paper has not been able to under take a very finely grained analysis of radical innovation within sub-sectors. However, this article has provided an important first step in identifying sectors that more micro-level analyses can explore in greater detail. Indeed, this paper has used the most recent, most authoritative and the largest available database to assess the extent to which the focus on the pharmaceutical industry is justified in other studies. That database is disaggregated in two important ways. Firstly, other studies, such as the one by the MIP, group chemical and pharmaceutical companies together under 'chemical'. This article's findings, which are based on the more nuanced IAB survey, are, therefore, based on relatively distinct manufacturing sectors. Secondly, the IAB database is conducted at the establishment rather than the company level. This, as noted above, has a number of benefits.

As is the case with all research based on cross-sectional data, this research is restricted by conventional limitations of cross-sectional studies, such as the attribution of the direction of causation. However, this is not a problem here as the results clearly indicate that being a radical innovator is not associated in a statistically significant way with just one or two sectors. Moreover, the analysis here focuses on associations between radical innovation and an establishment's sector. In short, it argues, in essence, that radical innovation is not only associated with the pharmaceutical industry. Furthermore, it is, arguably, difficult to conceive that radical innovation causes sector of establishment. 
Finally, this paper has, because of data limitations, not been able to compare the prevalence of radical innovation in the same sector across different countries. However, this does not detract from the aim of this paper, which is to assess whether or not the search for radical innovation in CMEs needs to be extended beyond the pharmaceutical industry. Notwithstanding this, international comparative studies would be an ideal way to assess the main claims of the $\mathrm{VoC}$ literature on institutions and innovation, as it would enable a systematic assessment of the ways in which institutional frameworks, including public policies, shape firms' abilities to develop key competitive capabilities. However, comparable highly disaggregated surveys with the same questions, measurement item, measurement scales which would be necessary for direct international comparisons with the respective variables of the IAB database, do not exist for major LMEs, such as the US and the UK. Future research could attempt to address this issue, but this would require large-scale international comparative surveys with variables that allow for direct comparisons. Nevertheless, this study has identified a number of sectors where this cross-national analysis might focus. For instance, cross-national research that has explicitly sought to examine the central claim of the $\mathrm{VoC}$ approach has, within manufacturing, tended to focus on the pharmaceutical industry.

This study's findings strongly suggest that the 'scientific instruments' sector would, in particular, appear to be worthy of further study. This is not just because the socio-economic institutions typically associated with Germany may, as noted above, be, in some instances, beneficial to radical innovation in this sector, but also because the evidence here and elsewhere (Allen et al., 2006) strongly suggests that German firms are able to compete internationally in a sector that has often been associated with radical innovation. Therefore, the scope of future research should be widened. In addition, establishments within the 'radio, television and communications equipment', 'scientific instruments', 'electrical machinery', and 'chemicals excluding pharmaceuticals' sectors appear worthy of further study, as they were not associated, in a statically significant way, with a lower propensity to introduce radical innovations compared to workplaces in the 'pharmaceutical' industry. To be sure, some research in this vein has been conducted; however, it often examines service sectors rather than manufacturing ones (see, for instance, Casper and Whitley, 2004; Crouch and Voelzkow, 2009).

Indeed, it is not just different sectors that should be scrutinised further, but sub-sectors within them. For instance, different sub-sectors within the chemical industry may be fruitfully assessed. As the results from this sector show, there may be substantial variation within the activities of firms within broader groupings. However, this sector is, on the whole, not one that is considered to be characterised by radical innovation. Despite this general characterisation, the results here suggest that, in Germany, the development of new technologies in the chemical sector is no less likely than it is in the pharmaceutical industry. This, therefore, indicates that the range of activities that organisations within the chemical industry engage in should be scrutinised more closely, as they may be more diverse than previously thought. Consequently, the impact of national institutional frameworks on firms' development of new technologies may be more variable within sectors than is currently thought.

Such studies would enable a more comprehensive assessment of these claims within the VoC literature that relate to radical innovation - and, indeed, to innovation, more generally - to be made. Ideally, assessment should be made across sectors (or sub-sectors) and across countries. They should be sufficiently finely grained to analyse important aspects of the innovation process. For instance, they should be able to reveal 
the type of knowledge that firms require to develop new technologies. For example, is it tacit and widely distributed? Similarly, these studies should be able to distinguish between various types of employees that such companies rely on. Another important area in such analyses is likely to be corporate funding, as different sub-sectors within the same industry may have contrasting financing needs in terms of the amount of money required as well as the anticipated length of time before investors can make any profit. Arguably, such a deeper understanding of the innovation characteristics of different sub-sectors is needed, as these qualities help to shape the typical coordination and control problems that firms must overcome if they are to be successful in developing new technologies and, hence, the capabilities that they will have to develop and maintain (Allen and Whitley, 2011). The abilities of strategic actors to generate and sustain these competencies will, in turn, be shaped by their socio-economic institutional setting (Hall and Soskice, 2001a; Ragwitz et al., 2007; Whitley, 2007). This, then, points to a more nuanced understanding of innovation and the influences of institutions on firms' organisational capabilities. Additionally and equally importantly, an examination of the development of new technologies in a broader range of sectors and sub-sectors would contribute towards significant debates on the diversity of organisational forms and institutional frameworks within VoC (Allen and Aldred, 2011; Allen and Whitley, 2011; Lane and Wood, 2009).

Together, these points suggest, firstly, that it is too early to conclude that firms in Germany attempting to introduce radical innovations will be at an institutional disadvantage compared to those in LMEs. Important similarities and differences in the characteristics associated with the development of new technologies in distinct (sub-)sectors are likely to exist. Secondly and consequently, public policies adopted by national and state governments may be able to foster radical innovation in certain sub-sectors without jeopardising Germany's traditional strengths in the areas of incremental innovation. Indeed, as the research has clearly shown, despite prominent arguments to the contrary, works councils and sectoral collective agreements are not impediments to radical innovation in Germany. Therefore, efforts to promote the development of new technologies should focus on other public-policy areas.

For the wider literature, the results suggest that radical innovation may not be confined to a few sectors of the economy, but may be more widely distributed. As the findings of this paper suggest, radical innovation may even be present in sectors that have, traditionally, been characterised as being dominated by incremental innovation. This, in turn, raises the possibility that radical innovation may be achieved in different ways in various sectors. For instance, radical innovation in the scientific-instruments sector may require long-term obligational forms of coordination both within and between firms. Yet, theory to date has often emphasised the need for intra- and inter-firm flexibility if companies are to be successful in developing new technologies. If radical innovation does have different characteristics in various sectors, this is likely to make the already difficult tasks of designing public policies to promote radical innovation even harder, as a policy that supports the development of a new technology in one (sub-)sector may not - and may, indeed, hinder it - in another.

\section{Acknowledgements}

This article draws on data from the IAB 2007 Betriebspanel. The authors are grateful to IAB employees, especially Dr. Peter Jacobebbinghaus, for their indefatigable assistance. 


\section{References}

Addison, J.T., Bellmann, L., Schnabel, C. and Wagner, J. (2004) 'The reform of the German works constitution act: a critical assessment', Industrial Relations, Vol. 43, No. 2, pp.392-420.

Allen, M.M.C. (2004) 'The varieties of capitalism paradigm: not enough variety?', Socio-Economic Review, Vol. 2, No. 1, pp.87-107.

Allen, M.M.C. and Aldred, M.L. (2011) 'Varieties of capitalism, governance, and high-tech export performance: a fuzzy-set analysis of the new EU member states', Employee Relations, Vol. 33, No. 4, pp.348-367.

Allen, M.M.C. and Whitley, R. (2011) 'Capabilities, sectors and institutions: the influence of sectoral variations and dominant institutions on firms' responses to increasing internationalization', in Lane, C. and Wood, G.T. (Eds.): Capitalist Diversity and Diversity within Capitalism, pp.140-162, Routledge, London.

Allen, M.M.C., Funk, L. and Tüselmann, H-J. (2006) 'Can variation in public policies account for differences in comparative advantage?', Journal of Public Policy, Vol. 26, No. 1, pp.1-19.

Audretsch, D. and Aldridge, T. (2008) Radical Innovation: Literature Review and Development of an Indicator, Draft Report to International Consortium on Entrepreneurship, available at http://ice.foranet.dk/upload/radical_innovation_audretsch_draft_2_.pdf (accessed on 11 March 2011).

Aviso (2008) Automated Selection and Harvesting of Pluripotent Stem Cell Colonies using the CellCelector, available at http://wa3230.mj13.de/cms/upload/PDF/Aviso_Application_Note_PDF1.pdf (accessed on 13 August 2010).

Block, F. and Keller, M.R. (2009) 'Where do innovations come from? Transformations in the US economy, 1970-2006', Socio-Economic Review, Vol. 7, No. 3, pp.459-483.

Bluhm, K. and Martens, B. (2009) 'Recomposed institutions: smaller firms' strategies, shareholder-value orientation and bank relationships in Germany', Socio-Economic Review, Vol. 7, No. 4, pp.585-604.

Börsch, A. (2008) 'Institutional variation and coordination patterns in CMEs: Swiss and German corporate governance in comparison', in Hancké, B., Rhodes, M. and Thatcher, M. (Eds.): Beyond Varieties of Capitalism: Conflict, Contradictions, and Complementarities in the European Economy, pp.173-194, Oxford University Press, Oxford.

Casper, S. (2009) 'Can new technology firms succeed in coordinated market economies? A response to Herrmann and Lange', Socio-Economic Review, Vol. 7, No. 2, pp.209-215.

Casper, S. and Matraves, C. (2003) 'Institutional frameworks and innovation in the German and UK pharmaceutical industry', Research Policy, Vol. 32, No. 10, pp.1865-1879.

Casper, S. and Whitley, R. (2004) 'Managing competences in entrepreneurial technology firms: a comparative institutional analysis of Germany, Sweden, and the UK', Research Policy, Vol. 33, No. 1, pp.89-106.

Casper, S., Lehrer, M. and Soskice, D. (1999) 'Can high-technology industries prosper in Germany? Institutional frameworks and the evolution of the German software and biotechnology industries', Industry and Innovation, Vol. 6, No. 1, pp.5-24.

Crouch, C. and Voelzkow, H. (2009) Innovation in Local Economies: Germany in Comparative Context, Oxford University Press, Oxford.

Culpepper, P.D. (2001) 'Employers' associations, public policy, and the politics of decentralized cooperation in Germany and France', in P.A. Hall and D. Soskice (Eds.): Varieties of Capitalism: The Institutional Foundations of Comparative Advantage, pp.275-306, Oxford University Press, Oxford and New York.

Dahlin, K.B. and Behrens, D.M. (2005), 'When is an invention really radical? Defining and measuring technological radicalness', Research Policy, Vol. 34, No. 5, pp.717-737.

Dosi, G., Gambardella, A., Grazzi, M. and Orsenigo, L. (2006) 'Technological revolutions and the evolution of industrial structures: assessing the impact of new technologies upon the size and boundaries of firms', Capitalism and Society, Vol. 3, No. 1, Article 6. 
Fioretos, O. (2001), 'The domestic sources of multilateral preferences: varieties of capitalism in the European community', in Hall, P.A. and Soskice, D. (Eds.): Varieties of Capitalism: The Institutional Foundations of Comparative Advantage, pp.213-246, Oxford University Press, Oxford.

Hall, P.A. and Soskice, D. (2001a) The Varieties of Capitalism: The Institutional Foundations of Comparative Advantage, Oxford University Press, Oxford.

Hall, P.A. and Soskice, D. (2001b) 'Introduction', in Hall, P.A. and Soskice, D. (Eds.): Varieties of Capitalism: The Institutional Foundations of Comparative Advantage, pp.1-68, Oxford University Press, Oxford.

Herrmann, A.M. (2008), 'Rethinking the link between labour market flexibility and corporate competitiveness: a critique of the institutionalist literature', Socio-Economic Review, Vol. 6, No. 4, pp.637-669.

Höpner, M. (2004) 'Unternehmensmitbestimmung unter Beschuss. Die Mitbestimmungsdebatte im Lichte der sozialwissenschaftlichen Forschung', Industrielle Beziehungen, Vol. 11, No. 4, pp.347-379.

IAB (2007) Beschäftigungstrends: Arbeitgeberbefragung 2007 im Auftrag der Bundesagentur für Arbeit, available at http://doku.iab.de/fdz/iabb/fb_2007.pdf (accessed on 13 August 2010).

Kölling, A. (2000) 'The IAB-establishment panel', Schmollers Jahrbuch - Zeitschrift für Wirtschafts- und Sozialwissenschaften, Vol. 120, No. 2, pp.291-300.

Kraft, K., Stank, J. and Dewenter, R. (2011) 'Co-determination and innovation', Cambridge Journal of Economics, Vol. 35, No. 1, pp.145-172.

Lane, C. and Wood, G. (2009), 'Capitalist diversity and diversity within capitalism', Economy and Society, Vol. 38, No. 4, pp.531-551.

Lange, K. (2009) 'Institutional embeddedness and the strategic leeway of actors: the case of the German therapeutical biotech industry', Socio-Economic Review, Vol. 7, No. 2, pp.181-207.

Lettl, C., Herstatt, C. and Gemuenden, H.G. (2006) 'Users' contributions to radical innovation: evidence from four cases in the field of medical equipment technology', $R \& D$ Management, Vol. 36, No. 3, pp.251-272.

Lilien, G.L., Morrison, P.D., Searls, K., Sonnack, M. and Von Hippel, E. (2002) 'Performance assessment of the lead user idea-generation process for new product development', Management Science, Vol. 48, No. 8, pp.1042-1059.

Lorenz, E. and Lundvall, B-Å. (2006) 'Understanding European systems of competence building', in Lorenz, E. and Lundvall, B-Å. (Eds.): How Europe's Economies Learn: Co-ordinating Competing Models, pp.1-25, Oxford University Press, Oxford.

Marsili, O. and Verspagen, B. (2002), 'Technology and the dynamics of industrial structures: an empirical mapping of Dutch manufacturing', Industrial and Corporate Change, Vol. 11, No. 4, pp.791-815.

Menard, S. (1995) Applied Logistic Regression Analysis, Sage University Series on Quantitative Applications in the Social Sciences 07-106, Sage, Thousand Oaks, CA.

Myers, R. (1990) Classical and Modern Regression with Applications, second ed., Duxbury, Boston, MA.

Nonaka, I. and Peltokorpi, V. (2006) 'Knowledge-based view of radical innovation: Toyota Prius case', in Hage, J. and Meeus, M. (Eds.): Innovation, Science and Institutional Change: A Research Handbook, pp.88-104, Oxford University Press, Oxford.

OECD (2008) Manufacturing Industries Classified According to their Global Technological Intensity (ISIC Revision 2 and NACE Revision 1.1), available at http://epp.eurostat.ec.europa.eu/cache/ITY_SDDS/Annexes/reg_hrst_base_an3.pdf (accessed on 14 September 2009).

Pavitt, K. (1984) 'Sectoral patterns of technical change: towards a taxonomy and a theory', Research Policy, Vol. 13, No. 6, pp.343-373. 
Phelps, E. (2007) 'Innovative thinking for European business', Financial Times, 17 December, available at http://www.ft.com/cms/s/0/37a80fc6-ac42-11dc-82f0-0000779fd2ac.html (accessed on 13 August 2010).

Ragwitz, M., Huber, C. and Resch, G. (2007) 'Promotion of renewable energy sources: effects on innovation', International Journal of Public Policy, Vol. 2, Nos. 1/2, pp.32-56.

Slocum, A. and Rubin, E.S. (2008) Understanding Radical Technology Innovation and its Application to CO2 Capture R\&D: Interim Report, Volume One - Literature Review, available at http://repository.cmu.edu/cgi/viewcontent.cgi?article=1069\& context=epp (accessed on 11 March 2011).

Streeck, W. (1992) Social Institutions and Economic Performance: Studies of Industrial Relations in Advanced Capitalist Economies, Sage Publications, London.

Streeck, W. (1997) 'Beneficial Constraints: on the economic limits of rational voluntarism' in Hollingsworth, J.R. and Boyer, R. (Eds.): Contemporary Capitalism: The Embeddedness of Institutions, pp.197-219, Cambridge University Press, Cambridge.

Tether, B.S. (2002) 'Who co-operates for innovation, and why: an empirical analysis', Research Policy, Vol. 31, No. 6, pp.947-967.

Tüselmann, H-J., McDonald, F., Heise, A., Allen, M.M.C. and Voronkova, S. (2007) Employee Relations in Foreign-Owned Subsidiaries: German Multinational Companies in the UK, Palgrave Macmillan, London.

Tylecote, A. and Ramirez, P. (2006) 'Corporate governance and innovation: The UK compared with the US and 'insider' economies', Research Policy, Vol. 35, No. 1, pp.160-180.

Von Hippel, E., Thomke, S.H. and Sonnack, M. (2000) 'Creating breakthroughs at 3M', Health Forum Journal, Vol. 43, No. 4, pp.20-27.

Walz, R. (2007) 'The role of regulation for sustainable infrastructure innovations: the case of wind energy', International Journal of Public Policy, Vol. 2, Nos. 1/2, pp.57-88.

Whitley, R. (2007) Business Systems and Organizational Capabilities The Institutional Structuring of Competitive Competences, Oxford University Press, Oxford. 